\title{
Pengaruh Penambahan Bakteri Lactobacillus casei dan Bakteri Zymomonas mobilis terhadap Aktivitas Antioksidan pada Yogurt
}

\author{
Herdayanto S. Putro, Rara F.L., Abharina, Refdinal, N. \\ Laboratorium Kimia Mikroorganisme \\ Departemen Kimia, Fakultas Sains Institut Teknologi Sepuluh Nopember Surabaya \\ *Corresponding author: hsputro@chem.its.ac.id
}

\begin{abstract}
Yogurt as milk fermentation product has been studied for several years and quite popular. In this study, Zymomonas mobilis and Lactobacillus casei bacteria were added to yogurt with the aim of studying their effects on antioxidant activity. Antioxidant activity was evaluated using DPPH radical compounds on pure yogurt, yogurt with the addition of Z. mobilis bacteria, and yogurt with the addition of $L$. casei bacteria in a row that obtained \% inhibition values of $88.87 \%, 91.64 \%, 98.70 \%$. Based on this study it can be concluded that the addition of $Z$. mobilis and L. casei bacteria can increase antioxidant activity in yogurt.
\end{abstract}

Keywords: Yogurt, Zymomonas mobilis, Lactobacillus casei, Antioxidants

\begin{abstract}
Abstrak
Yogurt merupakan produk fermentasi susu yang telah diteliti selama beberapa tahun dan produk fermentasi ini sudah terbukti dan popular. Pada penelitian ini, bakteri Zymomonas mobilis dan Lactobacillus casei ditambahkan ke dalam yogurt dengan tujuan mempelajari pengaruhnya pada aktivitas antioksidan. Aktivitas antioksidan dievaluasi menggunakan senyawa radikal DPPH pada yogurt murni, yogurt dengan penambahan bakteri Zymomonas mobilis, dan yogurt dengan penambahan bakteri Lactobacillus casei secara berturut-turut diperoleh nilai \%inhibisi sebesar 88,87\%, 91,64\%, dan 98,70\%. Dengan demikian, berdasarkan penelitian ini dapat disimpulkan bahwa penambahan bakteri Zymomonas mobilis dan Lactobacillus casei dapat meningkatkan aktivitas antioksidan pada yogurt.
\end{abstract}

Kata kunci: Yogurt, Zymomonas mobilis, Lactobacillus casei, Antioksidan 


\section{Pendahuluan}

Yogurt merupakan produk yang diperoleh dari olahan susu yang telah dipasteurisasi kemudian difermentasi dengan bakteri tertentu sampai diperoleh keasaman bau dan rasa yang khas, dengan atau tanpa penambahan bahan yang diizinkan [1]. Bentuknya mirip bubur atau es krim tetapi dengan rasa agak asam. Yogurt merupakan produk fermentasi susu yang diberi tambahan bakteri sebagai starter. Jenis bakteri yang digunakan adalah Streptococcus thermophiles dan Lactobacillus bulgaricus, bakteri-bakteri ini yang akan memicu proses fermentasi dari susu yaitu mengubah laktosa pada susu menjadi asam laktat [2].

Yogurt juga lebih kaya gizi daripada susu sebagai bahan dasar dalam pembuatan yogurt, hal ini dikarenakan meningkatnya total padatan sehingga kandungan zat-zat gizi lainnya meningkat. Yogurt kaya akan protein, kalsium, riboflavin, vitamin B6 dan vitamin B12 [3]. Selain itu yogurt dapat membantu proses pencernaan, meningkatkan kekebalan tubuh, mengurangi diare, diet dan melindungi dari kanker [4]. Bahkan ada kelebihan yogurt yang tidak dimiliki oleh susu murni, salah satunya yaitu sangat cocok dikonsumsi oleh penderita yang tidak toleran terhadap laktosa (Lactose Intolerance) [5].
Tidak hanya bakteri-bakteri tersebut penambahan bakteri Lactobacillus casei dan Zymomonas mobilis dapat meningkatkan kandungan glukosa, protein, dan lemak pada yogurt [6]. Sedangkan Lactobacillus casei mampu mengurangi produksi senyawa galaktosa yang biasanya dihasilkan saat pembuatan yogurt. Galaktosa dalam jumlah besar dapat mengganggu kesehatan [7]. Zymomonas mobilis diperoleh dari fermentasi ekstrak tanaman tropis dan sebagai salah satu agen fermentasi untuk pembuatan alkohol atau pada produksi bioetanol [8]. Ketika berinteraksi dengan sel di gastrointestinal, probiotik yang terkandung dalam susu fermentasi dapat meningkatkan beberapa aktivitasnya, antara lain aktivitas antiinflamasi [9]. Aktivitas antioksidan [10] aktivitas antimikroba, dan aktivitas penghambatan inhibitor enzim angiotensin I [11].

Berdasarkan ulasan di atas, dalam penelitian ini akan dilakukan penambahan bakteri Lactobacillus casei dan Zymomonas mobilis kedalam yogurt dengan tujuan untuk mengidentifikasi perbedaan aktivitas antioksidan pada yogurt dengan adanya pengaruh bakteri probiotik, dibandingkan dengan tanpa ditambahkan bakteri probiotik. 


\section{Metode Penelitian}

\section{Alat dan Bahan}

Alat yang digunakan dalam penelitian ini adalah neraca digital OHAUS analitik, kaca arloji, spatula besi, pengaduk kaca, autoclave, cawan petri, jarum ose, laminary flow, parafilm, inkubator, plastik wrap, aluminium foil, $\mathrm{pH}$ meter digital Senz $\mathrm{pH}$ Trans Instruments, botol semprot, corong, pipet tetes, kuvet plastik, kuvet kaca, tabung reaksi dan rak, pipet ukur $1 ; 2 ; 10 \mathrm{~mL}$, propipet, labu ukur $250 \mathrm{~mL}$, botol cokelat, oven, lemari pendingin, pipet mikro 1000 $\mu \mathrm{L}$. Instrumen yang digunakan adalah spektrofotometer Genesys IOS UV-Vis. Bahan yang digunakan pada penelitian ini adalah bibit yogurt yang mengandung strain bakteri Lactobacillus bulgaricus, strain bakteri Streptococcus thermophilus, dan strain bakteri Lactobacillus acidophilus, susu sapi murni, strain bakteri Lactobacillus casei, strain bakteri Zymomonas mobilis, medium Nutrient Broth (NB), Agar Powder, etanol 70\%, aquades, aqua DM, methanol, DPPH (2,2-difenil-1-pikrilhidrazil).

\section{Prosedur Kerja}

Regenerasi Bakteri Lactobacillus casei dan Zymomonas mobilis

Masing-masing bakteri (strain bakteri Lactobacillus casei, strain bakteri Zymomonas mobilis) diinokulasikan pada cawan petri berbeda yang berisi Nutrient DOI: http://dx.doi.org/0.12962/j25493736.v5i1.5823
Agar yang telah disterilkan dalam autoclave dan diinkubasi selama kurang lebih 24 jam pada suhu masing-masing $37{ }^{\circ} \mathrm{C}$ dan $30{ }^{\circ} \mathrm{C}$.

\section{Pembuatan Kurva Pertumbuhan Bakteri}

Bakteri Lactobacillus casei dan bakteri Zymomonas mobilis dari hasil regenerasi, sebanyak 1 mata ose masing-masing diinokulasikan ke dalam $600 \mathrm{~mL}$ Nutrient Broth medium dalam erlenmeyer $1000 \mathrm{~mL}$ yang berbeda, kemudian erlenmeyer berisi bakteri Lactobacillus casei diinkubasi pada suhu $37^{\circ} \mathrm{C}$ dan erlenmeyer berisi bakteri Zymomonas mobilis diinkubasi pada suhu $30^{\circ} \mathrm{C}$. Kedua erlenmeyer diinkubasi didalam autoshacker dengan kecepatan $180 \mathrm{rpm}$. Optical density diukur pada panjang gelombang $600 \mathrm{~nm}\left(\mathrm{OD}_{600}\right.$, Absorbansi $1 \approx 1$ x $10^{9} \mathrm{sel} / \mathrm{ml}$ kultur) dengan spektrofotometri UV-Vis setiap jamnya. Dibuat kurva dengan absorbansi sebagai fungsi waktu.

\section{Persiapan Kultur Starter Bakteri}

Sebanyak dua labu erlenmeyer $100 \mathrm{~mL}$ yang telah disterilkan disiapkan dan kedalamnya dimasukkan $10 \mathrm{~mL}$ susu sapi yang telah dipasteurisasi pada suhu $85^{\circ} \mathrm{C}$ selama 10 menit dan didiamkan sampai suhu $40^{\circ} \mathrm{C}$. Kemudian ke dalam masing-masing labu erlenmeyer dimasukkan satu mata ose bakteri Zymomonas mobilis dan bakteri Lactobacillus casei lalu dikocok perlahan. Kultur starter bakteri Zymomonas mobilis diinkubasi pada suhu $37^{\circ} \mathrm{C}$ dan kultur starter 
bakteri Lactobacillus casei diinkubasi pada suhu $30^{\circ} \mathrm{C}$ selama 24 jam.

\section{Pembuatan Yogurt}

Bibit yogurt berupa serbuk yang berisi Lactobacillus bulgaricus, Streptococcus thermophilus, dan Lactobacillus acidophilus sebanyak 20 g dicampurkan ke dalam 150 $\mathrm{mL}$ air mineral, dikocok hingga bibit yogurt terlarut dan diinkubasi pada suhu $30^{\circ} \mathrm{C}$ selama 24 jam sampai starter yogurt menjadi kental. Setelah itu bibit yogurt dipindahkan ke dalam susu. $50 \mathrm{~mL}$ bibit dapat dicampurkan ke dalam 1 liter susu pasteurisasi, sehingga $150 \mathrm{~mL}$ bibit yogurt dapat digunakan untuk 3 liter susu pasteurisasi. Diinkubasi selama 12 jam pada suhu $30^{\circ} \mathrm{C}$. Hasil produksi berupa yogurt yang dapat digunakan.

\section{Penambahan Mikroba Probiotik Pada}

\section{Yogurt}

Yogurt yang telah dibuat masingmasing dimasukkan ke dalam erlenmeyer $100 \mathrm{~mL}$ yang telah diberi label $\mathrm{A}, \mathrm{B}$, dan $\mathrm{C}$ sebanyak $50 \mathrm{ml}$. Erlenmeyer A sebagai kontrol. Pada erlenmeyer B ditambahkan 2,5 mL kultur starter bakteri L. casei, dan pada erlenmeyer $\mathrm{C}$ ditambahkan 2,5 mL kultur starter bakteri Zymomonas mobilis. Kemudian, erlenmeyer A (kontrol) dan erlenmeyer B diinkubasi pada suhu $37^{\circ} \mathrm{C}$ sedangkan erlenmeyer C diinkubasi pada suhu $30^{\circ} \mathrm{C}$ selama 24 jam.

\section{Pengukuran pH}

Kontrol dan sampel yang telah dibuat dimasukkan ke dalam gelas beaker dan masing-masing diukur pH-nya menggunakan $\mathrm{pH}$-meter.

\section{Uji Aktivitas Antioksidan dengan Metode DPPH}

Pengukuran aktivitas antioksidan dengan menggunakan metode DPPH $(1,1-$ difenil-2-pikrilhidrazil) sebagaimana yang telah dilakukan oleh deng,dkk. 2014. Satu mililiter sampel dan kontrol yogurt masingmasing ditambah dengan $9 \mathrm{~mL}$ larutan $\mathrm{DPPH}$ $60 \mu \mathrm{M}$. Campuran yang dihasilkan kemudian dihomogenkan dan diinkubasi pada suhu ruang selama 30 menit. Pengukuran absorbansi dilakukan dengan menggunakan spektrofotometer UV-Vis pada panjang gelombang maksimum $517 \mathrm{~nm}$. Pengukuran absorbansi diulangi sebanyak tiga kali. Hasil analisa aktivitas antioksidan dinyatakan dalam bentuk persentase (\%) inhibisi, yang juga melambangkan \% aktivitas penghambatan radikal bebas. Persentase penghambatan dapat dihitung dengan persamaan 3.1.

$$
\text { \%Inhibisi }=1-\left(\frac{\text { Absorbnsi sampel }}{\text { Absorbansi kontrol }}\right) \times 100 \%
$$




\section{Hasil dan Pembahasan}

\section{Regenerasi Bakteri Lactobacillus casei dan} Zymomonas mobilis

Pada penelitian ini bakteri yang digunakan adalah Lactobacillus casei dan Zymomonas mobilis yang didapatkan dari NITE Biological Resource Center (NBRC, Jepang). Bakteri tersebut diinokulasi menggunakan jarum ose dengan metode goresan kuadran pada cawan petri yang berisi media agar steril nutrient agar (NA). Pemilihan NA sebagai media inokulasi karena kandungan nutrisi NA yang lengkap serta sesuai dengan kebutuhan nutrisi bakteri dalam proses perkembang biakannya. Komposisi NA terdiri dari pepton, ekstrak daging, $\mathrm{NaCl}$, dan agar. Pepton merupakan sumber nitrogen yang kaya akan senyawa nitrogen bebas yang sederhana. Nitrogen memiliki fungsi sebagai prekursor untuk mensintesis asam amino, protein, dan enzim serta membentuk sel baru oleh bakteri.

Ekstrak daging merupakan sumber karbohidrat, protein, vitamin B kompleks, dan mineral (kalsium, sulfur, fosfat, kalium, dll) bagi bakteri. Vitamin B kompleks berfungsi sebagai senyawa katalitik dalam sel dan sebagai faktor koenzim atau grup prostetik enzim. Karbohidrat berfungsi sebagai sumber karbon dalam pembentukan energi yang dibutuhkan pada metabolisme dan pertumbuhan bakteri. $\mathrm{NaCl}$ selain menjadi faktor yang dapat menaikkan tekanan osmosis juga berfungsi sebagai penyedia unsur mikro (natrium) dan keseimbangan psikokimia pada sel bakteri. Kemudian agar berfungsi sebagai medium pengeras ketika dilarutkan dalam air dan disterilisasi untuk memastikan mikroorganisme lain tidak hidup dalam media tersebut [12].

Inkubasi Lactobacillus casei dilakukan suhu $37^{\circ} \mathrm{C}$, dimana suhu ini merupakan suhu optimum untuk pertumbuhan bakteri Lactobacillus casei [13]. Setelah diinkubasi selama 24 jam, diperoleh bakteri hasil kulturasi yang membentuk koloni-koloni. Bakteri Zymomonas mobilis diinkubasi pada suhu $30^{\circ} \mathrm{C}$, dimana suhu ini merupakan suhu optimum untuk pertumbuhan Zymomonas mobilis [14]. Setelah diinkubasi selama 24 jam, diperoleh bakteri hasil kulturasi yang membentuk koloni-koloni.

\section{Kurva Pertumbuhan Bakteri Regenerasi} Bakteri Lactobacillus casei dan

\section{Zymomonas mobilis}

Dari kurva pertumbuhan bakteri $L$. casei pada Gambar 1., diketahui L. casei mengalami empat fase dalam perkembangannya. Empat fase tersebut yaitu fase lag pada 0-9 jam inkubasi, fase eksponensial pada 9-17 jam inkubasi, fase stasioner pada 17-31 jam inkubasi, dan mulai pada fase kematian sekitar 31-35 jam 
inkubasi. Sehingga dapat ditentukan bahwa waktu yang tepat untuk memanen bakteri Lactobacillus casei dilakukan ketika peralihan antara fase eksponensial dengan fase stasioner, yaitu setelah 17 jam masa inkubasi.

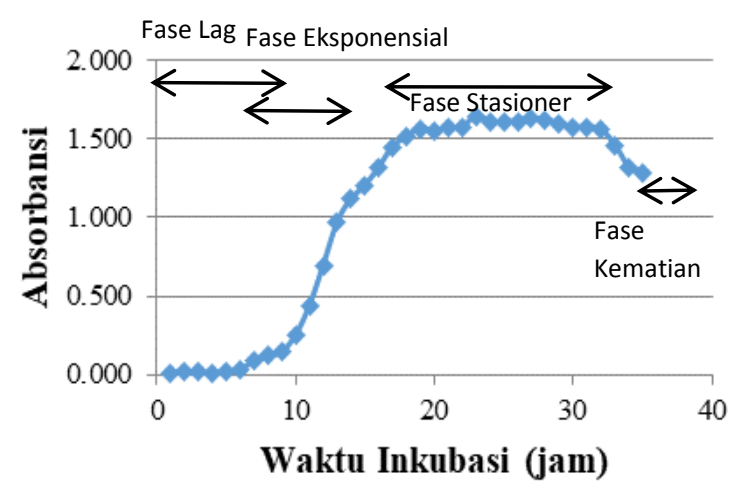

Gambar 1. Kurva Pertumbuhan L. Casei

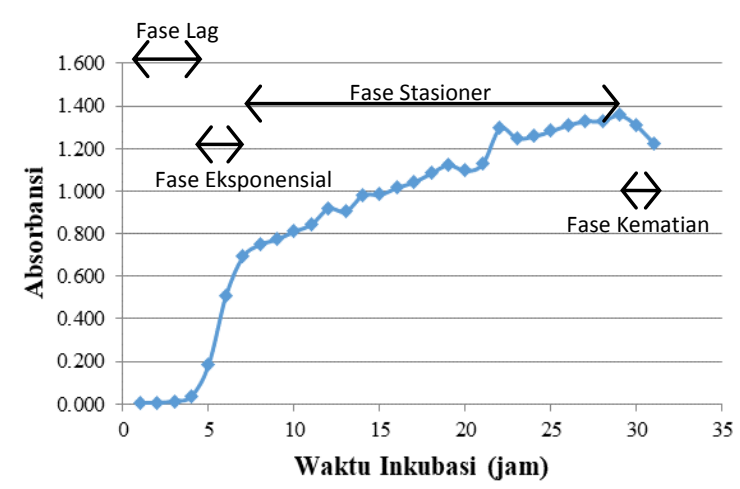

Gambar 2. Kurva Pertumbuhan Z. mobilis

Dari kurva pertumbuhan bakteri Zymomonas mobilis pada Gambar 2. diketahui Zymomonas mobilis mengalami empat fase dalam perkembangannya. Empat fase tersebut yaitu fase lag pada 0-4 jam inkubasi, fase eksponensial pada 4-7 jam inkubasi, fase stasioner pada 7-29 jam inkubasi, dan mulai pada fase kematian sekitar 29-31 jam inkubasi. Sehingga dapat DOI: http://dx.doi.org/0.12962/j25493736.v5i1.5823 ditentukan bahwa waktu yang tepat untuk memanen bakteri Zymomonas mobilis dilakukan ketika peralihan antara fase eksponensial dengan fase stasioner, yaitu setelah 7 jam masa inkubasi.

\section{Pembuatan Yogurt, Kultur Starter} Lactobacillus casei dan Zymomonas mobilis dan Penambahan Mikroba Probiotik pada Yogurt

Pada proses pembuatan yogurt, biakan yogurt berupa serbuk yang berisi Lactobacillus bulgaricus, Streptococcus thermophilus, dan Lactobacillus acidophilus dicampurkan ke dalam $150 \mathrm{~mL}$ air mineral, kemudian dikocok hingga bibit yogurt terlarut dan diinkubasi pada suhu $30^{\circ} \mathrm{C}$ selama 24 jam. Setelah inkubasi selama 24 jam, starter yogurt menjadi kental dan berwarna putih. Kemudian starter yogurt dipindah kedalam susu pasteurisasi, $50 \mathrm{~mL}$ starter dicampurkan kedalam 1 liter susu pasteurisasi sehingga $150 \mathrm{~mL}$ starter yogurt dapat digunakan untuk 3 liter susu pasteurisasi. Susu pasteurisasi yang telah ditambahkan starter yogurt diinkubasi selama 12 jam pada suhu $30^{\circ} \mathrm{C}$. Setelah inkubasi selama 12 jam, susu sudah mengental dan menjadi yogurt yang berwarna putih. Yogurt memiliki aroma asam yang khas.

Kultur starter bakteri berupa susu yang diberi tambahan bakteri Lactobacillus casei dan Zymomonas mobilis. Susu yang sudah 
diberi tambahan bakteri tetap berwarna putih, namun teksturnya lebih kental dibanding susu pasteurisasi.

Kultur starter bakteri Lactobacillus casei dan bakteri Zymomonas mobilis masing-masing ditambahkan kedalam yogurt sebanyak kedalam $50 \mathrm{~mL}$ yogurt. Setelah dinkubasi selama 24 jam, yogurt berwarna putih dan memiliki tekstur berupa cairan kental, memiliki bau khas yogurt yang normal, dan homogen. Hal ini sesuai dengan baku mutu, yang menerangkan bahwa yogurt memiliki tekstur berupa cairan kental-semi padat, memiliki bau khas yogurt/normal, dan homogen [15]

\section{Pengukuran pH Yogurt}

Penambahan bakteri Lactobacillus casei dan bakteri Zymomonas mobilis ke dalam yogurt adalah untuk meningkatkan nilai gizi dan fungsi dari yogurt. Dalam penelitian ini dilakukan pengukuran derajat keasaman $(\mathrm{pH})$ yogurt. Derajat keasaman (pH) yogurt dipengaruhi oleh jumlah asam laktat yang terbentuk selama proses inokulasi. Grafik hasil pengukuran $\mathrm{pH}$ yogurt sebelum dan setelah inkubasi selama 24 jam ditunjukkan pada Gambar 3.

Pada grafik $\mathrm{pH}$ yogurt menunjukkan nilai $\mathrm{pH}$ yogurt sebelum dan sesudah diinkubasi serta setelah ditambahkan bakteri Lactobacillus casei dan Zymomonas mobilis. Sebelum diinkubasi dan ditambahkan bakteri DOI: http://dx.doi.org/0.12962/j25493736.v5i1.5823 probiotik, $\mathrm{pH}$ yogurt sebesar 4.2. Hal ini sesuai dengan penelitian menyebutkan bahwa yogurt yang baik memiliki pH diantara 3,84,6 [16]. Yogurt yang ditambahkan bakteri Zymomonas mobilis mengalami penurunan $\mathrm{pH}$ menjadi 3,9 dan yogurt yang ditambahkan bakteri Lactobacillus casei mengalami penurunan $\mathrm{pH}$ menjadi 3,7. Selama proses fermentasi, bakteri akan memfermentasi karbohidrat yang ada sehingga terbentuk menjadi asam laktat. Pembentukan asam laktat ini menyebabkan peningkatan keasaman dan penurunan $\mathrm{pH}$ [17].

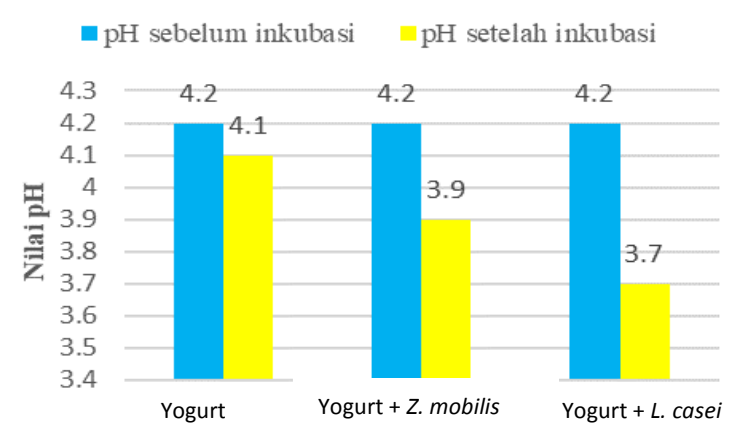

Tipe Yogurt

Gambar 3. Grafik pH Yogurt

\section{Uji Aktivitas Antioksidan Yogurt}

Pengujian aktivitas antioksidan pada penelitian ini menggunakan metode DPPH. Metode ini digunakan karena sederhana, cepat, sensitif dan produktif dibandingkan dengan metode lain. Prinsip pengujian metode ini didasarkan pada reduksi larutan DPPH dengan adanya antioksidan yang mendonorkan hidrogen, yang mengarah pada 
formasi bentuk non-radikal (DPPH - H). Antioksidan mampu mengurangi radikal stabil DPPH dengan adanya perubahan warna, dari yang semula radikal stabil berwarna ungu menjadi non radikal berwarna kuning yaitu diphenylpicrylhydrazine [18].

Pada penelitian ini, pengujian aktivitas antioksidan dilakukan pada panjang gelombang $517 \mathrm{~nm}$ [19]. Pengukuran persentase dekolorisasi dilakukan pada konsentrasi $100 \%$, karena merupakan kondisi optimum untuk mengukur persentase inhibisi. Grafik hubungan \% inhibisi dengan hari inkubasi dapat dilihat pada Tabel 1.

Tabel 1. Tabel \% inhibisi Sampel Uji

\begin{tabular}{|c|c|c|c|c|}
\hline \multirow{2}{*}{ Sampel } & \multicolumn{4}{|c|}{ \% Inhibisi Hari Ke- } \\
\cline { 2 - 5 } & $\mathbf{2}$ & $\mathbf{3}$ & $\mathbf{4}$ & $\mathbf{5}$ \\
\hline Yogurt & 22.97 & 78.95 & 88.87 & 60.27 \\
\hline $\begin{array}{c}\text { Yogurt + Z. } \\
\text { mobilis }\end{array}$ & 91.64 & 85.32 & 64.19 & 33.33 \\
\hline $\begin{array}{c}\text { Yogurt + L. } \\
\text { casei }\end{array}$ & 86.10 & 94.46 & 98.70 & 79.44 \\
\hline
\end{tabular}

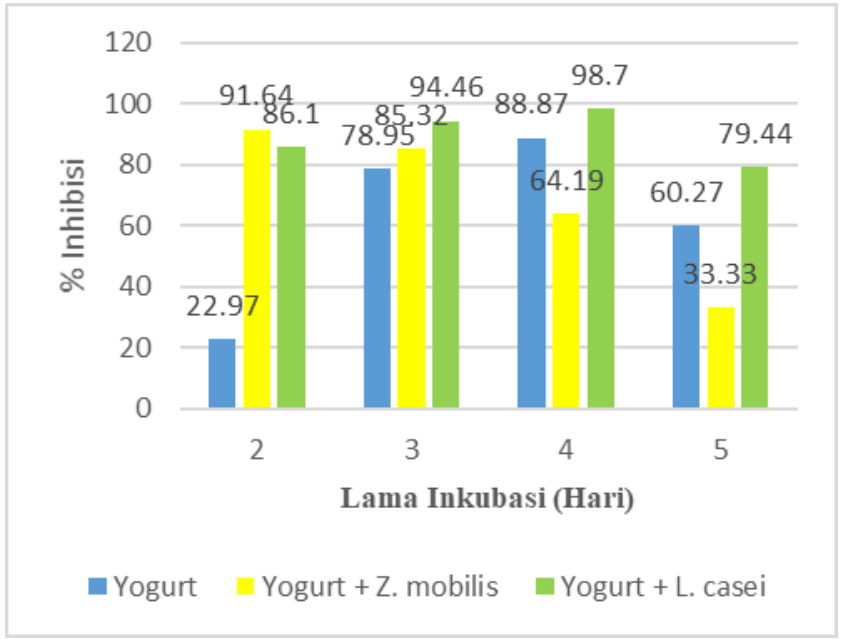

Gambar 4. Nilai Antioksidan Yogurt dalam $\%$ inhibisi
Pada gambar grafik 4. menunjukkan aktivitas antioksidan yogurt, yogurt dengan penambahan bakteri Zymomonas mobilis dan yogurt dengan penambahan bakteri Lactobacillus casei dari hari ke 2 hingga hari ke 5. Pada grafik tersebut menunjukkan aktivitas antioksidan yogurt murni meningkat dari hari ke 2 hingga hari ke 4 dimana peningkatan tersebut berbanding lurus dengan lama waktu fermentasi. Sedangkan pada hari ke 5 aktivitas antioksidan yogurt mengalami penurunan, yang diperkirakan terjadi kerusakan pada yogurt. Hal ini dikarenakan meningkatnya kadar asam pada yogurt yang diakibatkan oleh bakteri probiotik yang terkandung dalam starter yogurt yaitu Lactobacillus bulgaricus dan Streptococcus thermophillus yang merupakan bakteri asam laktat (BAL) [20].

Aktivitas antioksidan yogurt dengan penambahan bakteri Zymomonas mobilis sebesar 91,64\% pada hari ke-2 sedangkan pada hari berikutnya mengalami penurunan secara berurutan, yang berbanding terbalik dengan lama waktu fermentasi. Hal ini dikarenakan kemampuan bakteri Zymomonas mobilis yang mampu memproduksi etanol dengan memanfaatkan glukosa sebagai sumber energi dalam siklus glikolisis yang menghasilkan asam piruvat. Kemudian katabolisme asam piruvat akan menghasilkan etanol dan $\mathrm{CO}_{2}$. Semakin lama waktu 
fermentasi maka nutrisi dalam yogurt akan semakin berkurang dengan adanya jumlah sel yang semakin bertambah dan dapat mengakibatkan kompetisi yang akhirnya akan memasuki fase kematian [21]. Selanjutnya, aktivitas antioksidan yogurt dengan penambahan bakteri Lactobacillus casei menunjukkan hasil yang sangat baik pada hari ke 3 hingga hari ke 4 yang mengalami peningkatan hingga $98.70 \%$ dan mengalami penurunan pada hari ke 5. Hal ini dikarenakan kemampuan Lactobacillus casei untuk memproduksi asam-asam organik terutama asam laktat yang akan menurunkan $\mathrm{pH}$ yogurt sehingga menyebabkan aktivitas antioksidan semakin rendah [22].

\section{Kesimpulan}

Pada penelitian ini telah dilakukan penambahan bakteri Zymomonas mobilis dan bakteri Lactobacillus casei pada fermentasi yogurt. Penambahan tersebut dapat meningkatkan aktivitas antioksidan yang ditunjukkan dengan $\%$ inhibisi. Nilai \% inhibisi optimum pada yogurt dan yogurt dengan penambahan bakteri Lactobacillus casei diperoleh pada hari ke-empat inkubasi dan nilai $\%$ inhibisi optimum pada yogurt dengan penambahan bakteri Zymomonas mobilis diperoleh pada hari ke-dua. Dimana nilai \% inhibisi yogurt, yogurt yang diberi tambahan bakteri Zymomonas mobilis dan yogurt yang diberi tambahan bakteri
Lactobacillus casei berturut-turut sebesar $88,87 \%, \quad 91,64 \%, \quad 98,70 \%$. Berdasarkan penelitian ini maka dapat disimpulkan bahwa penambahan bakteri Zymomonas mobilis dan Lactobacillus casei dapat meningkatkan aktivitas antioksidan pada yogurt. Saran untuk penelitian berikutnya terkait penurunan kandungan antioksidan pada yogurt yang ditambahkan Z. mobilis adalah pengendalian jumlah kadar etanol yang dihasilkan dengan metode fortifikasi selama proses fermentasi.

\section{Daftar Pustaka}

[1]BSN, B. S. N. (1992). Yogurt.

[2] Vedamuthu, E. R. (2006). Other Fermented and CultureContaining Milks, 295-308.

[3] Ashraf, R., \& Shah, N. P. (2011). International Journal of Food Microbiology Selective and differential enumerations of Lactobacillus delbrueckii subsp bulgaricus , Streptococcus thermophilus, Lactobacillus acidophilus , Lactobacillus casei and $\mathrm{Bi}$ fi dobacterium spp . in yoghurt - A review. International Journal of Food Microbiology, 149(3), 194-208.

https://doi.org/10.1016/j.ijfoodmicro.2011 .07 .008

[4]Hassan, A., \& Amjad, I. (2010). Nutritional evaluation of yoghurt prepared by different starter cultures and their 
physiochemical analysis during storage, 9(20), 2913-2917.

[5]Wahyudi, M. (2006). Proses Pembuatan dan Analisis Mutu Yoghurt. Jurnal Buletin Teknik Pertanian, 11.

[6] Krisdianto, B. Cahyo (2019). Pengaruh penambahan Bakteri Lactobacillus casei dan Zymomonas mobilis terhadap Kandungan Nutrisi (Glukosa, Protein, dan Lemak) Yogurt. Surabaya : ITS Press.

[7]Qinglong Wu, Nagendra P. Shah. 2016. The potential of species-specific tagatose6-phosphate (T6P) pathway in Lactobacillus casei group for galactose reduction in fermented dairy foods. Food and Nutritional Science, School of Biological Sciences. Pokfulam Road, Hong Kong : The University of Hong Kong.

[8] Yanase H, Nozaki K, Okamoto K. 2005. Ethanol production from cellulosic materials by genetically engineered Zymomonas mobilis. Biotechnol. Lett. 27(4):259-263.

[9] de Assis, P. O. A., G. C. B. Guerra, D. F. de Souza Araújo, R. F. de Araújo Júnior, T. A. D. G. Machado, A. A. de Araújo, T. A. S. de Lima, H. E. M. Garcia, and R. C. R. do Egypto. 2016. Intestinal antiinflammatory activity of goat milk and goat yoghurt in the acetic acid model of rat colitis. Int. Dairy J. 56:45-54.
[10] Srivastava, P., S. G. M. Prasad, M. N. Ali, and M. Prasad. 2015. Analysis of antioxidant activity of herbal yoghurt prepared from different milk. Pharma Innovation J. 4:18-20

[11] Abd El-Gawad, I. A., E. M. El-Sayed, H. M. El-Zeini, S. A. Hafez, and F. A. Saleh. 2014. Antibacterial activity of probiotic yoghurt and soy-yoghurt against Escherichia coli and Staphylococcus aureus. J. Nutr. Food Sci. 4:1-6.

[12] Sutarma. 2000. Kultur Media Bakteri. Temu Teknis Fungsional non Peneliti. 52- 57.

[13] Todar, Kenneth. 2006. Todar's online textbook of bacteriology. University of Wisconsin-Madison Department of Bacteriology.

[14] Titus, A. dan G.N. Pereira. 2007. The role of actinomycetes in coffe plantation ecology.

at http://www.ineedcoffee.com/05/actinom ycetes/. Diakses 2018.

[15] Badan Standar Nasional Indonesia (BSN) 2981-2009.

[16] Allgeyer, L. C., M. J. Miller and S. Y. Lee. 2010. Sensory and microbiological quality of yogurt drinks with prebiotics and probiotics. J. Dairy Sci. 93: 44714479 . 
[17] Frazier, W. C., \& Westhoff, P. C. (1988). Food Microbiology. New Delhi: Tata McGraw-Hill Company Limited

[18] Milardovic S, Damir Ivekovic, Bozidar S. Grabaric. 2006. A novel amperometric method for antioxidant activity determination using DPPH free radical. Volume 68, Issue 2, May 2006, Pages $175-180$

[19] Campos J. F, Uilson Pereirados Santos , Luis Fernando Benitez Macorini, Adriana Mary Mestriner Felipede Melo , José Benedito Perrella Balestieri , Edgar JulianParedes-Gamero , Claudia Andrea Lima Cardoso , Kelyde Picoli Souza ,
Edson Lucasdos Santos. 2014. Antimicrobial, antioxidant and cytotoxic activities of propolis from Melipona orbignyi (Hymenoptera, Apidae). Volume 65, March 2014, Pages 374-380 [20] Yudoamijoyo, M., Darwis, A. A., \& Sa'id, E. G. (1992). Teknologi Fermentasi. Jakarta: Rajawali Press.

[21] Virtanen, T., Pihlanto, A., Akkanen, S., \& Korhonen, H. (2007). Development of antioxidant activity in milk whey during fermentation with lactic acid bacteria, $102,106-115$. https://doi.org/10.1111/j.13652672.2006.03072.x 